\title{
Fatty acid biosynthesis and transcriptional regulation of Stearoyl-CoA Desaturase 1 (SCD1) in buffalo milk
}

Zhipeng $\mathrm{Li}^{2 \dagger}$, Suyu Lư ${ }^{2+}$, Kuiqing Cui ${ }^{2}$, Laiba Shafique ${ }^{2}$, Saif ur Rehman², Chan Luo ${ }^{2}$, Zhiqiang Wang ${ }^{2}$, Jue Ruan?', Qian Qian ${ }^{1}$ and Qingyou Liu' ${ }^{1,2^{*}}$ (D)

\begin{abstract}
Background: Buffalo milk is considered as a highly nutritious food owing to its higher contents of fatty acids (FA) and rich nutrient profile. Higher fat contents of buffalo milk make it suitable for processing to develop various healthy and nutritious products. Moreover, buffalo milk contains more unsaturated FAs (UFA) such as oleic and linolenic acid, which are important from the human health point of view owing to their desirable physiological effects. However, inadequate information is available about the chemical composition and mechanism of FA synthesis in buffalo milk. In this study, we hypothesized that expression of SCD1 gene could alter the biosynthesis of FA in epithelial cells of mammary gland and subsequently affect the FA contents in buffalo milk. We investigated the transcriptional and biological role of Stearoyl-CoA Desaturase 1 (SCD1) in the buffalo mammary epithelial cells (BMECs) during FA and triacylglycerol (TAG) synthesis.
\end{abstract}

Results: Results revealed that unsaturated fatty acid contents were much higher in concentration in buffalo milk as compared to Holstein cow. Significant increase in the expression level of FAS, ACACA, SREBP1, PPARG, GPAT, and AGPAT genes was observed in response to altered expression of SCD1 in buffalo milk. Moreover, change in SCD1 gene in BMECs also mediated the expression of genes related to FA biosynthesis subsequently leading to alter the FA composition. Overexpression of SCD1 significantly increased the expression of genes associated with FA and TAG synthesis leading to enhance FA and unsaturated FA contents in BMECs. However, down-regulation of SCD1 exhibited opposite consequences.

Conclusion: Our study provides mechanistic insights on transcriptional regulation of SCD1 to alter FA and TAG synthesis through directly or indirectly mediating biosynthesis and metabolic pathways in BMECs. We provide preliminary findings regarding engineering of FA contents in buffalo milk through SCD1 signaling.

Keywords: SCD1, Buffalo milk, Fatty acid, RNA interference, Overexpression

\footnotetext{
* Correspondence: 408659358@qq.com

†Zhipeng Li and Suyu Lu contributed equally to this work.

${ }^{1}$ Agricultural Genomics Institute, Chinese Academy of Agricultural Sciences,

Shenzhen 518120, Guangdong, China

${ }^{2}$ State Key Laboratory for Conservation and Utilization of Subtropical

Agro-Bioresources, Guangxi University, Nanning 530005, Guangxi, China
}

(c) The Author(s). 2020 Open Access This article is licensed under a Creative Commons Attribution 4.0 International License, which permits use, sharing, adaptation, distribution and reproduction in any medium or format, as long as you give appropriate credit to the original author(s) and the source, provide a link to the Creative Commons licence, and indicate if changes were made. The images or other third party material in this article are included in the article's Creative Commons licence, unless indicated otherwise in a credit line to the material. If material is not included in the article's Creative Commons licence and your intended use is not permitted by statutory regulation or exceeds the permitted use, you will need to obtain permission directly from the copyright holder. To view a copy of this licence, visit http://creativecommons.org/licenses/by/4.0/ The Creative Commons Public Domain Dedication waiver (http://creativecommons.org/publicdomain/zero/1.0/) applies to the data made available in this article, unless otherwise stated in a credit line to the data. 


\section{Background}

Buffalo milk is the second most-produced milk in the world after cow milk and especially important in the Asian continent which inhabits more than $97 \%$ of the global buffalo population [1,2]. Buffalo milk is a rich source of fatty acids (FA) with high energetic and nutritive value. Higher fat contents of buffalo milk make it suitable for processing to develop various delicious, healthy and nutritious products. Moreover, Buffalo milk contains more unsaturated FAs (UFA) such as oleic and linolenic acid, which are important from human health point of view owing to their number of desirable physiological effects $[3,4]$. However, inadequate information is available about the chemical composition and mechanism of FA biosynthesis in buffalo milk.

Milk FAs are either de novo synthesized in the mammary gland or imported from the plasma. Signaling mechanisms of lipogenesis have been clearly described in rodent tissues [5], but limited studies are available in buffalo regarding this. However, studies have suggested that fat synthesis in the mammary gland may share a similar mechanism [6,7]. It has been also observed that main lipid metabolic pathways are controlled by DNAbinding activity and nuclear abundance of selected transcription factors of key regulatory genes [5, 8]. Major transcriptional factors involved in FA biosynthesis are sterol regulatory binding protein-1 (SREBP-1) and peroxisome proliferator-activated receptors (PPARs). FA or cholesterol can induce changes in the nuclear abundance of SREBP and bind to the nuclear receptors (PPAR). SREBP can bind with sterol binding elements or palindromic sequences on the promoter regions of its target genes such as acetyl-CoA carboxylase (ACACA), FA synthase $(F A S)$, and Stearoyl-CoA Desaturase $(S C D)$ [8]. An implication of PPARG in nutritional or insulin activation of lipogenesis has been observed by upregulation of PPARG, FAS and ACACA gene expression in bovine tissues [9]. The acetyl-CoA carboxylase (ACC) and FA synthase (FAS) enzymes (encoded by the $A C A C A$ and $F A S$ genes, respectively) are involved in the metabolic pathway for de novo FA synthesis [8]. The ACCA protein provides cytoplasmic malonyl-CoA for FA synthesis while FAS protein is mainly responsible for the synthesis of short- and medium-chain FA (C4-C16) [10].

In the mammary gland, $S C D$ is responsible for the synthesis of the major part of cis-9, trans-11- $[11,12]$ and of trans-7, cis-9 conjugated linoleic acids (CLA) [13]. These FAs can be desaturated by $S C D$ leading to the synthesis of cis-9 monounsaturated FA (MUFA), which are then esterified to glycerol sequentially by glycerol-3 phosphate acyl transferase (GPAT), acyl glycerol phosphate acyl transferase (AGPAT), and diacylglycerol acyl transferase (DGAT) [8]. The promoter region of bovine $\mathrm{SCD}$, especially the region containing the stearoyl-CoA desaturase transcriptional enhancer element, plays a key role in the inhibition of transcriptional activity of trans10, cis-12 CLA. It is recognized as a core gene involved in the FA and triacylglycerol (TAG) synthesis [14] and potential tool to study transcriptional regulation of milk quality.

Several studies have reported FA composition and physico-chemical characteristics of buffalo and cow milk; however, few studies have focused on illustration of molecular mechanisms. Therefore, present study was conducted to testify the hypothesis that transcriptional and biological role of SCD1 (during FA and TAG synthesis) affects the FA contents of Buffalo milk. Initially, we determined the FA composition of buffalo and cow milk and analyzed the expression pattern of the respective genes related to FA synthesis. Later on, association of SCD1 with selected genes was further studied by RNA interference (RNAi) and overexpression of SCD1 in Buffalo mammary epithelial cells (BMECs), to elucidate potential effects on FA compositions. Transcriptional regulation of SCD1 could be used to provide mechanistic insights on physicochemical characteristics of buffalo milk.

\section{Results}

\section{Routine analysis of Milk composition}

Chemical composition of Holstein cow and buffalo milk was evaluated including, butter fat, protein, lactose, and total solid and solid not fat contents (Table 1). Results revealed that lactose contents were comparable in cow and buffalo milk, while FA, protein, total solids and solid not fat contents were significantly higher in buffalo as compared to cow milk. The Highest difference was observed in butterfat contents which were 1.86 times higher in buffalo than cow milk ( $7.88 \pm 0.91$ vs $4.24 \pm 0.80)$.

\section{Analysis of FA composition of Milk}

Gas chromatography was used to analyze the FA composition of milk samples (Table 2). Results showed that FA contents of milk from both species were similar, except CLA and Eicosapentaenoic acid (EPA) which were only observed in buffalo milk. The C16:0 was major saturated FA (SFA) while C18:1 was major unsaturated

Table 1 Routine composition of milk in different cows

\begin{tabular}{llllll}
\hline Species & Fat \% & Protein \% & Lactose \% & Total solids \% & Solid not fat \% \\
\hline Holstein & $4.24 \pm 0.80^{\mathrm{a}}$ & $3.39 \pm 0.55^{\mathrm{a}}$ & $4.92 \pm 0.32$ & $13.40 \pm 1.36^{\mathrm{a}}$ & $9.17 \pm 0.58^{\mathrm{a}}$ \\
Buffalo & $7.88 \pm 0.91^{\mathrm{b}}$ & $5.37 \pm 0.32^{\mathrm{b}}$ & $4.99 \pm 0.41$ & $18.16 \pm 1.08^{\mathrm{b}}$ & $10.23 \pm 0.47^{\mathrm{b}}$ \\
\hline
\end{tabular}

Note: Different superscript letters means significantly different $(P<0.05)$ 
Table 2 FA composition of Holstein and buffalo milk

\begin{tabular}{|c|c|c|c|}
\hline Fat acid & & Holstein & Buffalo \\
\hline \multirow{11}{*}{$\begin{array}{l}\text { Saturated } \\
\text { Fat acid }\end{array}$} & $C 4: 0$ & $36.96 \pm 10.92^{a}$ & $94.49 \pm 13.39^{b}$ \\
\hline & C6:0 & $20.09 \pm 3.75^{a}$ & $116.2 \pm 9.98^{b}$ \\
\hline & C8:0 & $13.59 \pm 3^{a}$ & $73 \pm 6.41^{b}$ \\
\hline & C10:0 & $24.72 \pm 4.41^{a}$ & $151.27 \pm 11.23^{b}$ \\
\hline & C12:0 & $33.82 \pm 6.2^{\mathrm{a}}$ & $183.52 \pm 16.03^{b}$ \\
\hline & C14:0 & $105.2 \pm 19.7^{a}$ & $854.22 \pm 58.83^{b}$ \\
\hline & C15:0 & $0.94 \pm 0.17^{\mathrm{a}}$ & $10 \pm 1.27^{b}$ \\
\hline & C16:0 & $213.36 \pm 36.49^{a}$ & $2986.31 \pm 178.62^{b}$ \\
\hline & C17:0 & $7.37 \pm 1.74^{\mathrm{a}}$ & $81.52 \pm 8.62^{b}$ \\
\hline & C18:0 & $51.77 \pm 8.47^{a}$ & $957.3 \pm 114.08^{b}$ \\
\hline & Total & $507.82 \pm 94.85^{\mathrm{a}}$ & $5507.83 \pm 418.46^{b}$ \\
\hline \multirow{12}{*}{$\begin{array}{l}\text { Unsaturated } \\
\text { Fat acid }\end{array}$} & C14:1 & $11.55 \pm 1.76^{a}$ & $92.23 \pm 10.58^{b}$ \\
\hline & C16:1 & $22.06 \pm 4.7^{\mathrm{a}}$ & $247.68 \pm 33.77^{b}$ \\
\hline & C17:1 & $2.89 \pm 0.53^{a}$ & $29.58 \pm 3.2^{b}$ \\
\hline & C18:1 & $343.33 \pm 62.99^{a}$ & $2419.31 \pm 257.48^{b}$ \\
\hline & C18:2 & $28.97 \pm 5.88^{a}$ & $136.34 \pm 15.24^{b}$ \\
\hline & C18:3 & $5.76 \pm 1.49^{a}$ & $40.14 \pm 4.89^{b}$ \\
\hline & C20:1 & $1.89 \pm 0.53^{a}$ & $23.25 \pm 3.64^{b}$ \\
\hline & C20:2 & $1.2 \pm 0.17^{\mathrm{a}}$ & $3.62 \pm 0.45^{b}$ \\
\hline & C20:3 & $3.15 \pm 0.59^{a}$ & $14.21 \pm 1.39^{b}$ \\
\hline & CLA & - & $19.4 \pm 1.68^{\mathrm{a}}$ \\
\hline & EPA & - & $14.6 \pm 0.2^{\mathrm{a}}$ \\
\hline & Total & $449.45 \pm 78.62^{a}$ & $2959.94 \pm 327.72^{\mathrm{a}}$ \\
\hline Total & & $925.27 \pm 173.47^{a}$ & $8467.77 \pm 746.18^{b}$ \\
\hline
\end{tabular}

Note: "- " indicates undetectable; Different superscript letters mean significantly different $(P<0.05)$. All milk FA compositions were expressed as $\mathrm{mg} / 100 \mathrm{~g}$ of fat

FA (UFA) in milk as observed in our study. Each kind of FA and the total FA in Buffalo milk are all significantly richer than that of Holstein cows in terms of the FA content per $100 \mathrm{~g}$ of milk $(p<0.05)$.

\section{Expression of genes related to FA synthesis in Milk}

Expression of key genes related to milk fat synthesis in both species was detected by QRT- PCR. Results revealed radically higher expression level of genes related with fat synthesis including FA de novo synthesis related genes ( $F A S$ and $A C A C A)$, Glyceride synthesis related genes (GPAT and AGPAT6), and transcriptional regulator related genes (SREBP1 and PPARG) in buffalo as compared to cow milk (Fig. 1). In addition, the expression of $S C D 1$ in buffalo milk was about 123 times higher than that of cow, which indicates its key role in FA synthesis in milk.

Effect of SCD1 interference on expression of FA synthesis related genes and subsequent FA composition in BMECs The interference efficiency of the siRNA was detected first to confirm the feasibility of the siRNA. Results indicated that the transfection of siRNA1 and siRNA2 significantly decreased the expression of $S C D 1$ as compared to the control group, while siRNA3 and NCsiRNA exhibited no significant effect on expression level (Fig. 2). Keeping in view the greater potential of siRNA1 to interfere the expression of $S C D$ gene, it was selected for further study. After the transfection of BMECs with siRNA1 and NC-siRNA respectively, the expression of FA synthesis related genes was determined (Fig. 3). Results demonstrated that the expression of $S C D 1$ was significantly decreased (1/5th) as compared to blank control, indicating successful siRNA transfection. Expression of $F A S$ and $P P A R G$ considerably increased $(P<0.05)$, whereas expression of AGPAT6, ACACA, and GPAT gene decreased $(P<$ $0.05)$ after interference. However, $S C D 1$ interfering did not significantly affect the expression of SREBP1 $(P>0.05)$.

The FA contents extracted from cells were further analyzed by gas chromatography (Table 3 ). Results demonstrated that siRNA interference significantly increased $(P<0.05)$ SFA contents $(\mathrm{C} 16: 0$ and $\mathrm{C} 18: 0)$, while decreasing $(\mathrm{P}<0.05)$ UFA contents $(\mathrm{C} 16: 1$ and $\mathrm{C} 18: 1)$. Moreover, total SFA contents also significantly increased $(\mathrm{P}<0.05)$ while total UFA markedly decreased $(\mathrm{P}<0.05)$. Interestingly, no significant change $(P>0.05)$ was observed in the total FA contents of the BMECs.

\section{Effect of SCD1 overexpression on FA synthesis related genes and FA composition in BMECs}

After SCD1 overexpression, the expression of SCD1 increased up to 8 times more as compared to the blank control. The expression level of both FAS and ACACA was significantly downregulated, whereas expression of GPAT, SREBP1, PPARG and AGPAT was significantly enhanced (Fig. 4). The composition of FA that extracted from BMECs was also analyzed by applying Gas chromatography (Table 4). Overexpression of SCD1 in BMECs resulted in a significant $(P<0.05)$ decrease in SFA contents (C16:0 and C18:0) while increasing UFA (C16:1, C18:1 and C18:2) contents. Moreover, total FAs and UFA contents in the cells were increased significantly $(\mathrm{P}<0.05)$, while total SFA contents were decreased $(P<0.05)$.

\section{Summary of gene networks involved in Milk fat synthesis} The networks between SCD1 and genes related to FA synthesis in BMECs were analyzed (Fig. 5). Results revealed that knockdown of SCD1 can significantly decrease the expression of TAG biosynthesis related genes (GPAT and AGPAT6), while increasing the expression of FA synthesis genes as compared to control. Similarly, the expression of these genes showed the opposite trend when SCD1 was overexpressed, which was in accordance with the alteration of SCD1. Expression of the ACACA gene was decreased either due to SCD1 overexpression or siRNA treatment, despite the change induced by siRNA was not 


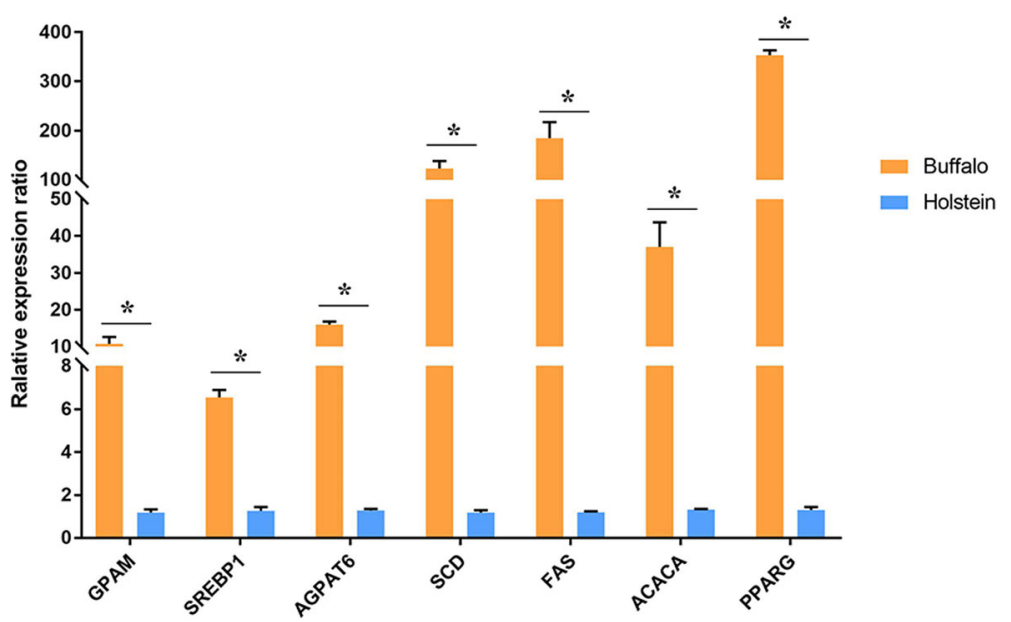

Fig. 1 Expression of genes related to FA synthesis in milk by qRT-PCR analysis. Note: Different superscript letters means significantly different $(P<0.05)$

significant. However, expression of transcription factor PPARG was significantly up-regulated regardless of overexpression or knockdown of SCD1. Furthermore, transcription factor SREBP was significantly up-regulated in response to SCD1 overexpression, but not markedly affected by the down regulation of SCD1.

\section{Discussion}

Milk is an important part of the human diet that provides nourishment and essential nutrients to the body. It is also relished by individuals and also used to make a variety of delicious and healthy food products. In our study, we observed significantly higher protein and FA contents (especially UFA) in buffalo milk as compared to cow milk. Similar findings have been reported earlier $[1,2]$. But we observed contrary findings regarding lactose contents which are generally reported higher in

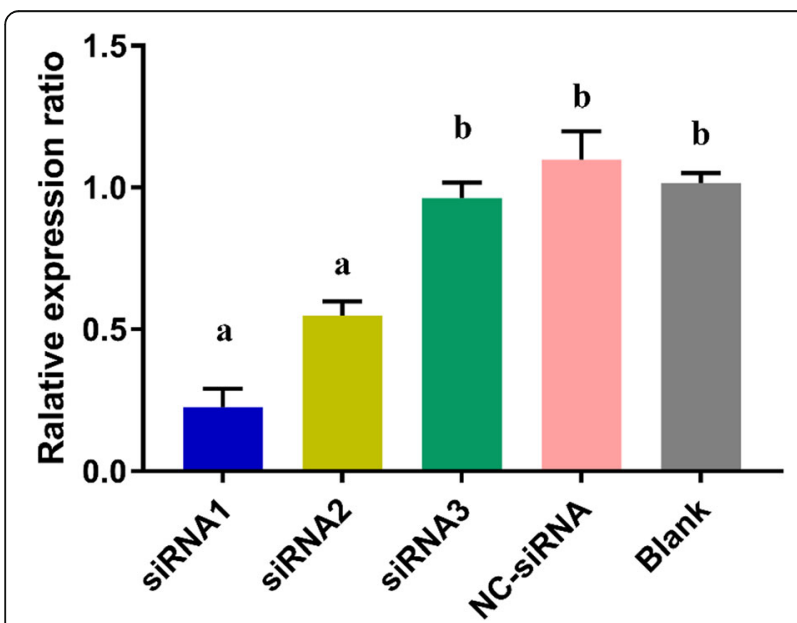

Fig. 2 The relative expression of SCD1 after siRNA interference. Note: Different superscript letters means significantly different $(P<0.05)$ buffalo milk compared to the cow [2]. This variation may be attributed to different dietary, environmental and physiological conditions of animals used in this study. However, this does not affect the buffalo milk quality and low lactose contents may be even beneficial for individuals having lactose intolerance [15].

In the present study, expression of genes responsible for FA de novo synthesis ( $F A S$ and $A C A C A$ ), TAG synthesis (GPAT and AGPAT) and transcription factors (SREBP1 and PPARG) was significantly higher in buffalo than cow. These findings support the evidence that higher FA contents in buffalo milk are associated with over expression of these genes, as reported earlier in goat and bovines [16-18].

Extensive studies conducted on lactation biology of bovine mammary gland have [19].SREBPs are transcriptional factors that regulate lipid homeostasis through controlling the expression of enzymes required for FA de novo synthesis. The mature SREBP is translocated to the nucleus, where it binds with its target genes, including $A C A C A, F A S, S C D 1$, and others [20]. Moreover, SREBP1 is a central element in the overall regulation of genes involved in milk fat synthesis [16, 21], and SCD1 is involved in the SREBP-1-regulated pathway during milk fat synthesis [22, 23]. Two isoforms of SREBP1 protein, SREBP1a and SREBP1c, usually exist in mammals which arise by the use of two alternative first exons. Exon 1a encodes the unique 29 amino acids of the SREBP1a NH2-terminus, whereas exon 1c only encodes 5 unique amino acids [24, 25]. Experiments in transfected cells have shown that SREBP-1c is a much weaker activator of transcription than SREBP-1a when both are simultaneously expressed [26]. However, the ratio of SREBP-1c to 1a transcripts has shown remarkable variation among different organs of adult mouse and human 


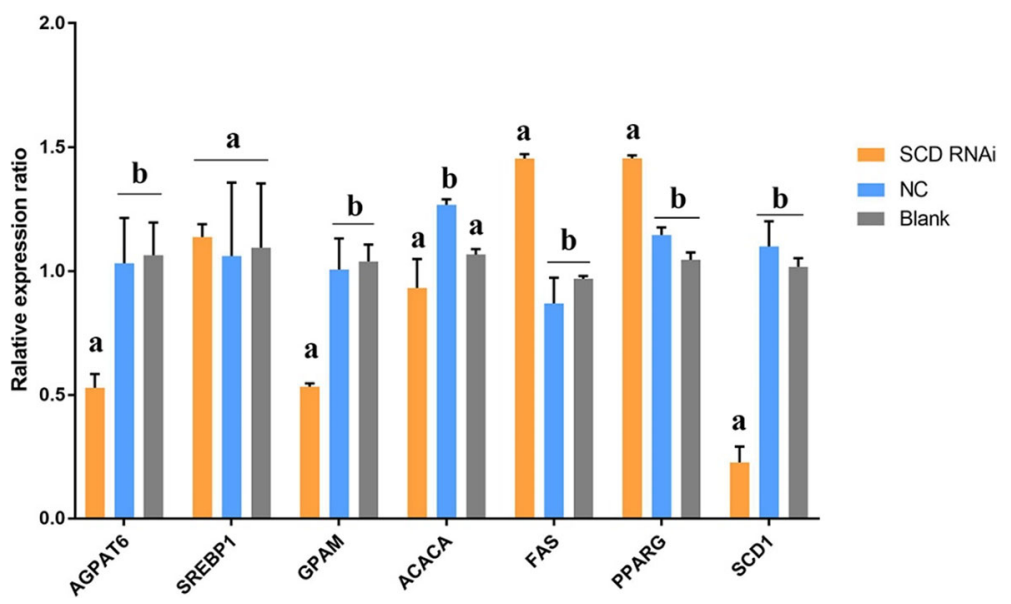

Fig. 3 Expression of FA synthesis related genes after SCD1 interference. Note: Different superscript letters means significantly different $(P<0.05)$

[25]. Considering the similar function of these two isoforms in the regulation of lipid homeostasis, our study did not show any variation in the transcription of both proteins. The primer of SREBP1 used in this study was spanning the exon 2 to exon 4, to amplify both SREBP1a and 1c. In the present study, change in mRNA levels of SREBP1in response to overexpression or RNAi of $S C D 1$ clearly demonstrated that SREBP1 could be regulated transcriptionally by $S C D 1$ in BMECs, which is consistent with earlier studies as mentioned above. PPARs belong to a superfamily of hormone receptors and regulate transcription of genes that are involved in different metabolic pathways of lipids, including transport of plasma triglycerides, cellular uptake of FA, and peroxisomal and mitochondrial $\beta$-oxidation [27].

It has been reported that activation of PPARG can regulate lipogenesis and expression of $F A S$ and $A C A C A$ [9]. Although, the activation of PPARG did not affect the expression of $S C D 1$ in rodents $[28,29]$, the positive effect in ruminants has been stated earlier [18, 23, 30].

Table 3 Effect of SCD1 interference on FA composition in BMECS

\begin{tabular}{|c|c|c|c|}
\hline Fat Acid & $\begin{array}{l}\text { Blank } \\
\text { control (mg) }\end{array}$ & $\begin{array}{l}\text { Negative } \\
\text { control (mg) }\end{array}$ & RNA interfered (mg) \\
\hline$\overline{C 16: 0}$ & $0.614 \pm 0.11^{a}$ & $0.591 \pm 0.11^{a}$ & $0.759 \pm 0.18^{b} \uparrow$ \\
\hline C16:1 & $0.279 \pm 0.06^{\mathrm{a}}$ & $0.226 \pm 0.03^{a}$ & $0.124 \pm 0.03^{\mathrm{b}} \downarrow$ \\
\hline C18:0 & $0.657 \pm 0.16^{a}$ & $0.547 \pm 0.07^{a}$ & $0.875 \pm 0.17^{b} \uparrow$ \\
\hline C18:1 & $0.873 \pm 0.10^{a}$ & $0.886 \pm 0.18^{a}$ & $0.613 \pm 0.15^{b} \downarrow$ \\
\hline C18:2 & $0.212 \pm 0.06$ & $0.203 \pm 0.02$ & $0.216 \pm 0.02$ \\
\hline Total SFA & $1.271 \pm 0.27^{a}$ & $1.138 \pm 0.17^{a}$ & $1.634 \pm 0.36^{\mathrm{b}} \uparrow$ \\
\hline Total UFA & $1.364 \pm 0.22^{\mathrm{a}}$ & $1.315 \pm 0.24^{a}$ & $0.953 \pm 0.20^{b} \downarrow$ \\
\hline Total & $2.535 \pm 0.49$ & $2.453 \pm 0.41$ & $2.587 \pm 0.56$ \\
\hline
\end{tabular}

Note: Different superscript letters means significantly different $(P<0.05)$. All milk FA compositions were expressed as $\mathrm{mg} / 100 \mathrm{~g}$ of fat. SFA Saturated Fat acid, UFA Unsaturated Fat acid
Our findings also confirmed the direct association of SCD1 with PPARG during FA synthesis. Furthermore, studies have also reported that expression of $S C D 1$ can be suppressed by the natural ligands of PPARG, palmitoleic acid and oleic acid, through a polyunsaturated FA response region (PUFA-RR) [31, 32]. Therefore, an appropriate ratio of intracellular oleic to stearic acid should be maintained for proper regulation of SCD1, SREBP1 and PPARG.

Several studies have demonstrated a significant association of polymorphism in $S C D 1$ with milk FA composition, which indicates the crucial role of $S C D 1$ in mammary FA and TAG synthesis [33-35]. Although $S C D 1$ is mainly involved in the synthesis of MUFA but it can also affect the synthesis of TAG. The MUFA catalyzed by SCD1 may even serve as a substrate for TAG synthesis in the mammary gland [36]. In the present study, SCD1 expression was associated with the expression of genes related to FA and TAG synthesis in BMECs which is in agreement with earlier studies mentioned above. Additionally, expression of enzymes involved in TAG synthesis including GPAT and AGPAT was also affected by altered expression of $S C D 1$. Increase of UFAs including C16:1, C18:1 and C18:2 in the BMECs in response to overexpression of SCD1 may be a cumulative outcome of $A C A C A$ and $F A S$ down-regulation together with upregulation of GPAT and AGPAT, which is supported by the evidence that medium and long chain FA are potent inhibitors of $A C A C A$ in the mammary gland [18, 37]. It can be envisaged that $S C D 1$ may corroborate with proteins which can inhibit the FA synthesis to maintain an appropriate FA synthesis and oxidation balance by altering its products. Studies have provided evidence that overexpression of SCD1 in $\mathrm{CHO}$ cells can lead to a significant increase in TAG synthesis while decreasing FA oxidation [38, 39]. Moreover, down-regulation of $S C D 1$ can lead to 


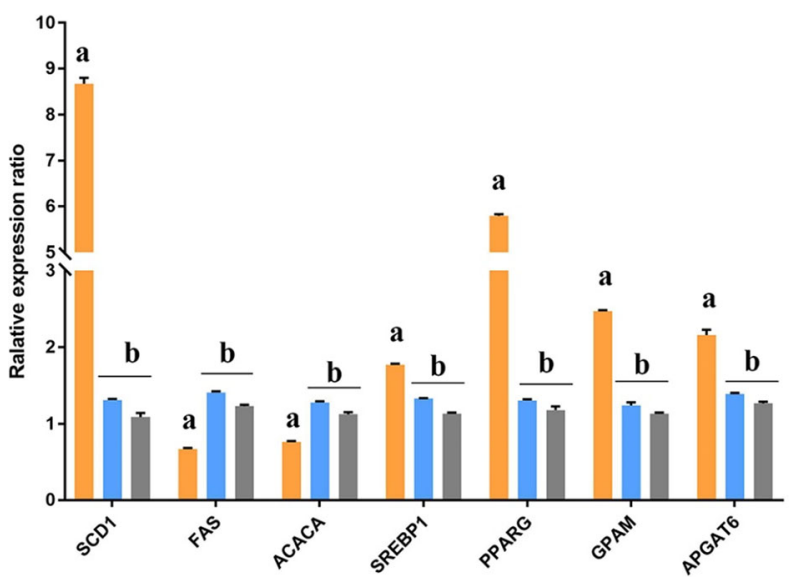

Fig. 4 Expression of FA synthesis related genes after SCD1 overexpression. Note: Different superscript letters means significantly different $(P<0.05)$

decrease in expression of genes related to TAG synthesis and results in lower cellular TAG contents in 3 T3-L1 preadipocytes [36], as observed in the present study. Moreover, down-regulation of gene expression in the mammary gland has been reported to contribute to the overall decrease in milk fat synthesis [40].

\section{Conclusion}

In conclusion, this study indicated that $S C D 1$ plays an important role in FA and TAG synthesis and can directly or indirectly affect fat metabolic pathways in BMECs. Our study provides mechanistic insights on transcriptional regulation of $S C D 1$ to alter FA and TAG synthesis through directly or indirectly mediating biosynthesis and metabolic pathways in BMECs. We provide the preliminary findings regarding the engineering of FA contents in buffalo milk through $S C D 1$ signaling; however, further studies are required to fully understand the mechanism to elaborate regulatory gene networks.

Table 4 Effect of SCD1 overexpression on FA composition in BMECs

\begin{tabular}{llll}
\hline Fat Acid & $\begin{array}{l}\text { Empty control } \\
(\mathrm{mg})\end{array}$ & $\begin{array}{l}\text { Negative control } \\
(\mathrm{mg})\end{array}$ & $\begin{array}{l}\text { Overexpressed } \\
(\mathrm{mg})\end{array}$ \\
\hline C16:0 & $0.614 \pm 0.11^{\mathrm{a}}$ & $0.602 \pm 0.09^{\mathrm{a}}$ & $0.403 \pm 0.10^{\mathrm{b}} \downarrow$ \\
C16:1 & $0.279 \pm 0.05^{\mathrm{a}}$ & $0.256 \pm 0.06^{\mathrm{a}}$ & $0.486 \pm 0.09^{\mathrm{b}} \uparrow$ \\
C18:0 & $0.657 \pm 0.16^{\mathrm{a}}$ & $0.642 \pm 0.12^{\mathrm{a}}$ & $0.319 \pm 0.05^{\mathrm{b}} \downarrow$ \\
C18:1 & $0.873 \pm 0.11^{\mathrm{a}}$ & $0.821 \pm 0.15^{\mathrm{a}}$ & $1.276 \pm 0.17^{\mathrm{b}} \uparrow$ \\
C18:2 & $0.212 \pm 0.06^{\mathrm{a}}$ & $0.197 \pm 0.06^{\mathrm{a}}$ & $0.354 \pm 0.03^{\mathrm{b}} \uparrow$ \\
Total SFA & $1.271 \pm 0.27^{\mathrm{a}}$ & $1.244 \pm 0.22^{\mathrm{a}}$ & $0.722 \pm 0.16^{\mathrm{b}} \downarrow$ \\
Total UFA & $1.364 \pm 0.22^{\mathrm{a}}$ & $1.274 \pm 0.27^{\mathrm{a}}$ & $2.116 \pm 0.29^{\mathrm{b}} \uparrow$ \\
Total & $2.535 \pm 0.50^{\mathrm{a}}$ & $2.518 \pm 0.48^{\mathrm{a}}$ & $2.838 \pm 0.45^{\mathrm{b}} \uparrow$ \\
\hline
\end{tabular}

Note: Different superscript letters means significantly different $(P<0.05)$. SFA Saturated Fat acid, UFA Unsaturated Fat acid

\section{Methods}

Animals and sampling

Indigenous Holstein cows and purebred Mediterranean Buffaloes (Bubalus bubalis) imported from Italy in 2015 (by Guangxi HuaXu Buffalo Biotechnology co. LTD) were used for this study. All animals received humane care as outlined in the Guide for the Care and Use of Experimental Animals of the National Institutes of Health. Milk samples were collected from 30 Buffalos or Holstein cows in their 1st or 2nd parity and 100 150 days in lactation. We collected 30 samples from each species in this study and each milk sample were collected in triplicate until the composition (lactose, fat, protein, total solid and solid not fat) was determined by a milk analyzer (MilkoScan FT120, Denmark) immediately after collection. Milk samples were collected during the daily production without any needless hurt to the animal. BMECs of 2 lactigenous buffalo were collected from a slaughter house of Nanning (China) under sterile conditions. Instantaneous high-voltage shock was used to euthanasia the buffalo according to the Regulations for the Administration of Affairs Concerning Experimental Animals.

\section{Milk fat extraction and gas chromatography analysis}

Milk fat extraction and gas chromatography analysis were performed following the method reported by Mele [41]. In brief, two grams of milk sample was mixed with $0.4 \mathrm{~mL}$ of ammonia $25 \%, 1 \mathrm{~mL}$ of ethyl alcohol $95 \%$, and $5 \mathrm{~mL}$ of hexane, vortexed and centrifuged at $1600 \times \mathrm{g}$ at $4{ }^{\circ} \mathrm{C}$. The upper layer was collected, and a second extraction with $1 \mathrm{~mL}$ of ethyl alcohol $95 \%$ and $5 \mathrm{~mL}$ of hexane was performed. A third extraction was made by using 5 $\mathrm{mL}$ of hexane. The extracted fat was dried, weighed, and finally dissolved in hexane. FA composition was determined by gas chromatography using a Shimadzu GC- 


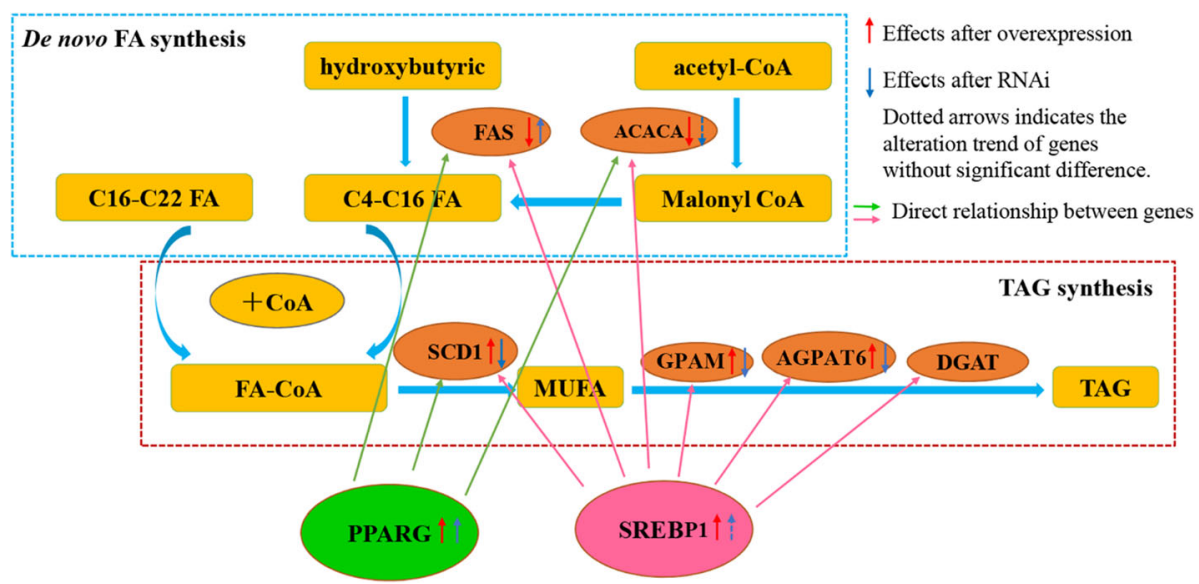

Fig. 5 Summary of SCD1 associated FA synthesis and metabolism signal pathways in BMECs

2014C (Kyoto, Japan) gas-chromatograph equipped with an FID and a capillary column (Agilent DB23, California, USA; $30 \mathrm{~m} \times 0.32 \mathrm{~mm}$ i.d.; film thickness $0.25 \mu \mathrm{m}$ ). Injection ported $230{ }^{\circ} \mathrm{C}$ and detector $280^{\circ} \mathrm{C}$. The column was kept at $180^{\circ} \mathrm{C}$ for $5 \mathrm{~min}$ and heated up to $230^{\circ} \mathrm{C}$ at $3{ }^{\circ} \mathrm{C}$ $\mathrm{min}^{-1}$. The carrier gas is kept in high-purity nitrogen and the injection volume is $1 \mu \mathrm{L}$. Individual FA methyl esters were identified by comparing them to a standard mixture of 37 Component FAME Mix (Supelco, Bellefonte, PA). The standards of PUFA-2, nonconjugated C18:2 isomer mixture, individuals cis-5,8,11,14,17 C20:5, cis-4,7,10,13,16,19 C22:6 (Supelco), cis-6,9,12 C18:3 and cis-9,12,15 C18:3 (Matreya Inc., Pleasant Gap, PA) were used to identify polyunsaturated FA. The identification of C18:1 isomer was based on commercial standard mixtures (Supelco) and published isomeric profiles (Wolff and Bayard, 1995). A nonadecanoic acid was used as an internal standard to increase the veracity of the peak normalization. For all studied FA, the coefficient of variation $[(\mathrm{SD} / \mathrm{mean}) \times 100]$ was $<3.5 \%$, suggesting good repeatability of GC data. All milk FA compositions were expressed as g per $100 \mathrm{~g}$ of fat.

\section{Total RNA isolation}

The total RNA in milk fat globules (MFG) was used for gene expression analysis as reported previously [42]. Milk samples were collected in the morning and mRNA was extracted immediately. The whole extraction process was performed at $4{ }^{\circ} \mathrm{C}$ (from the milk collection to the RNA extraction) and completed within $2 \mathrm{~h}$ to improve the quality of mRNA. Milk samples were centrifuged at $2000 \times g$ for $10 \mathrm{~min}$ at $4{ }^{\circ} \mathrm{C}$ to isolate milk fat. The supernatant fat layer was separated and $500 \mu \mathrm{L}$ fat was mixed with $1.5 \mathrm{~mL}$ of TRIzol LS solution (Invitrogen Life Technologies Inc., Carlsbad, CA). All the procedures were carried out at $4{ }^{\circ} \mathrm{C}$. RNA was dissolved in $30 \mu \mathrm{L}$ of RNase-free water and stored at $-80^{\circ} \mathrm{C}$. We further performed the agarose gel electrophoresis analysis and only the mRNA samples with a low $5 \mathrm{~s}$ band were selected for the following experiment.

\section{Single-Strand cDNA synthesis}

RNA purity was evaluated through absorbance readings (ratio of A260/A230 and A260/A280) by using a NanoDrop ND-2000 spectrophotometer (Thermo Fisher Scientific, Waltham, MA). Before first-strand cDNA synthesis, contaminated genomic DNA was removed by DNase treatment. First-strand cDNA was synthesized using RevertAid First Strand cDNA Synthesis Kit (K1622, Thermo Fisher Scientific, Waltham, MA). The singlestrand cDNA obtained was stored at $-20^{\circ} \mathrm{C}$.

\section{Primer designing and qRT-PCR}

Primers of the selected genes were designed by using the oligo 7 software (Table 5). The expressions of selected genes were quantified by using SYBR Green dye $(4,913$, 914,001, ROCHE) and fluorescence data were acquired using RT-PCR instrument (ABI 7500). A $20 \mu \mathrm{L}$ mixture was performed in each run as follows: $1 \mu \mathrm{L}$ cDNA, $8 \mu \mathrm{L}$ $\mathrm{H}_{2} \mathrm{O}, 10 \mu \mathrm{L}$ Faststart Universal SYBR Green Master (ROX), and $0.5 \mathrm{uM}$ aliquots of both forward and reverse primers. The thermal cycling profile started with a 3min dwell temperature of $94{ }^{\circ} \mathrm{C}$, followed by 40 cycles of $30 \mathrm{~s}$ at $94^{\circ} \mathrm{C}, 30 \mathrm{~s}$ at the primer specific annealing temperature $\left(60^{\circ} \mathrm{C}\right), 30 \mathrm{~s}$ at $72^{\circ} \mathrm{C}$, and a final step during which fluorescence was acquired. After 40 cycles, a melting curve was generated by temperature increments of $0.1^{\circ} \mathrm{C}$ starting three 3 times, and relative gene expression was calculated using the $2^{-\triangle \triangle \mathrm{Ct}}$ method using GAPDH as a reference gene as reported previously [43].

\section{Construction of Lentiviral vector and synthesis of siRNA}

The SCD1 gene was cloned from buffalo mammary epithelial cells according to the SCD1 sequence available in 
Table 5 Primers used for real-time quantitative PCR

\begin{tabular}{|c|c|c|c|}
\hline Target genes & Primer Sequences $\left(5^{\prime} \sim 3^{\prime}\right)$ & $\operatorname{Tm}\left({ }^{\circ} \mathrm{C}\right)$ & GenBank Accession No. \\
\hline $\mathrm{SCD1}$ & $\begin{array}{l}\text { F: TCCTGTTGTTGTGCTTCATCC } \\
\text { R: GGCATAACGGAATAAGGTGGC }\end{array}$ & 59 & AY241933 \\
\hline FAS & $\begin{array}{l}\text { F: GCAAAGTGGTCATTCAGGTACG } \\
\text { R: CCCAGTGATGATGTAGCTCTTG }\end{array}$ & 60 & KM980092.1 \\
\hline PPARG & $\begin{array}{l}\text { F: CAGTGTCTGCAAGGACCTCA } \\
\text { R: GTAAAAGGCATGGGAGTGAT }\end{array}$ & 59 & HG270143.1 \\
\hline SREBP1 & $\begin{array}{l}\text { F: CTGACGACCGTGAAAACAGA } \\
\text { R: AGACGGCAGATTTATTCAACTT }\end{array}$ & 58 & KU517672.1 \\
\hline GPAT & $\begin{array}{l}\text { F: GCAGGTTTATCCAGTATGGCATT } \\
\text { R: GGACTGATATCTTCCTGATCATCTTG }\end{array}$ & 59 & AY515690.1 \\
\hline AGPAT6 & $\begin{array}{l}\text { F: AAGCAAGTTGCCCATCCTCA } \\
\text { R: AAACTGTGGCTCCAATTTCGA }\end{array}$ & 59 & DY208485 \\
\hline ACACA & $\begin{array}{l}\text { F: TCCTGCTGCTATCGCTACTCCA } \\
\text { R: CGCACTCACATAACCAACCAT }\end{array}$ & 61 & DQ773054.1 \\
\hline GAPDH & $\begin{array}{l}\text { F: TGGAAAGGCCATCACCATCT } \\
\text { R:CCCACTTGATGTTGGCAG }\end{array}$ & 60 & NM001034034.1 \\
\hline
\end{tabular}

GenBank (No. AY241933) and inserted into lentiviral vector. The siRNA targeting SCD1 gene were designed and synthesized by Gene Pharma (Shanghai, China) with a control sequence (Table 6). Lentiviral vectors containing the SCD1 gene and the siRNA with negative control (NC) were constructed by Gene Pharma (Shanghai, China). The lentiviral vectors were packaged and propagated in $293 \mathrm{~T}$ cell line with the packaging plasmid $(\triangle \mathrm{NRF})$ and envelope plasmid encoding the vesicular stomatitis Virus-G glycoprotein (VSVG).

\section{Cell culture}

The BMECs were cultured and purified as reported previously $[44,45]$. Briefly, during lactation fresh tissue blocks from buffalo were obtained and washed 3 times and the acinus portion was extracted from mammary gland tissue and transferred into high-resistance PBS (containing $400 \mathrm{IU} \mathrm{mL}^{-1}$ of penicillin and $400 \mathrm{IU} \mathrm{mL}^{-1}$ of streptomycin). Then tissue pieces were placed in culture dishes on a clean bench, cut into 1 to $2 \mathrm{~mm}$ pieces and tiled on the bottom of the culture dish and cultured in the incubator for $4 \mathrm{~h}$. Then they were inverted and

Table 6 siRNA sequence target SCD1

\begin{tabular}{ll}
\hline siRNA target SCD1 & Sequence (5' to 3') $^{\prime}$ \\
\hline SiRNA-1 & GCCCAAGCUUGAGUAUGUUTT \\
siRNA-2 & AACAUACUCAAGCUUGGGCTT \\
& GCCCUAUAUGGGAUCACAUTT \\
siRNA-3 & AUGUGAUCCCAUAUAGGGCTT \\
& GGAGUCACCGAACCUACAATT \\
SiRNA-NC & UUGUAGGUUCGGUGACUCCTT \\
& UUCUCCGAACGUGUCACGUTT \\
& ACGUGACACGUUCGGAGAATT \\
\hline
\end{tabular}

cultured in the upright position overnight. The epithelial cells started to grow after about 12 days and epithelial cells were isolated by using trypsin digestion combined with a cell adherence speed method. The purification procedure was performed 3 times and the BMECs at 3 to 4 generation in the subculture were used for the following studies;

\section{Infection and transfection}

Transfection of the lentiviral vectors was carried out by using the Lipofectamine ${ }^{\text {Tx }} 2000$ (Invitrogen, USA). $100 \mu \mathrm{M}$ lentiviral vectors containing siRNA or SCD1 gene were used in each transfection and the transfected confluent cells were harvested for qRT-PCR analysis, $24 \mathrm{~h}$ post transfection.

\section{Statistical analysis}

All experiments were repeated three times. Results were expressed as mean \pm standard error (SEM). Statistical analysis was performed by using Student's t-test and analysis of variance (ANOVA) with DUNCAN's Multiple Range Test (DMR) in SPSS 17.0 software (IBM Corp., Armonk, NY). Differences of $P<0.05$ were considered to be significant.

\section{Abbreviations \\ ACACA: Acetyl-coenzyme A carboxylase alpha; AGPAT: Acyl glycerol phosphate acyl transferase; DGAT: Diacylglycerol acyltransferase; FAS: Fatty acid synthase; GPAT: Glycerol-3 phosphate acyl transferase; MUFA: Monounsaturated fatty acid; PPARY: Peroxisome proliferator activated receptor gamma; PUFA: Polyunsaturated fatty acid; SCD: Stearoyl-CoA desaturase; SCFA: Short chain fatty acid; SFA: Saturated fatty acid; UFA: Unsaturated fatty acid}

\section{Acknowledgements}

We acknowledge the Core facility center of the State Key Laboratory for Conservation and Utilization of Subtropical Agro-bioresources (Guangxi University) for the assistance of LC-MS/MS analysis in this study. 


\section{Authors' contributions}

LQY and CKQ designed the experiment; LZP and LSY performed the experiment, analyzed data and discussed the results and implications; LC and WZQ provided help in data analysis; LZP drafted the manuscript, LS, RJ, QQ and SR provided help in language editing. All authors read and approved the final manuscript.

\section{Funding}

This work was supported by the Chinese National Natural Science Foundation (Grant No.31860638 and 31760648) and Guangxi key research and development plan (Grant No. AA17204051, AB16380042 and AB18221120). None of the funding body had any influence on study design, data analysis, and interpretation, or in writing the manuscript.

\section{Availability of data and materials}

The dates generated and analyzed during this study are included in this paper. Additional datasets used and/or analyzed during the current study are available from the corresponding author on reasonable request.

\section{Ethics approval and consent to participate}

The Animal Care and Use Committee of the Guangxi University (Nanning, China) approved all procedures and experiments. All animals received humane care as outlined in the Guide for the Care and Use of Experimental Animals of the National Institutes of Health.

\section{Consent for publication}

Not applicable.

\section{Competing interests}

The authors declare that they have no competing interests.

\section{Received: 24 October 2019 Accepted: 21 February 2020}

Published online: 02 March 2020

\section{References}

1. Ménard O, Ahmad S, Rousseau F, et al. Buffalo vs. cow milk fat globules: size distribution, zeta-potential, compositions in total fatty acids and in polar lipids from the milk fat globule membrane. Food Chem. 2010;120(2):544-51.

2. Ahmad S, Gaucher I, Rousseau F, et al. Effects of acidification on physicochemical characteristics of buffalo milk: a comparison with cow's milk. Food Chem. 2008;106(1):11-7.

3. Massaro M, Carluccio MA, De Caterina R. Direct vascular antiatherogenic effects of oleic acid: a clue to the cardioprotective effects of the Mediterranean diet. Cardiologia. 1999:44(6):507-13.

4. Pariza MW, Park Y, Cook ME. The biologically active isomers of conjugated linoleic acid. Prog Lipid Res. 2001;40(4):283-98.

5. Clarke SD. Nonalcoholic steatosis and steatohepatitis. I. Molecular mechanism for polyunsaturated fatty acid regulation of gene transcription Am J Physiol Gastrointest Liver Physiol. 2001;281(4):G865-9.

6. Baumgard LH, Corl BA, Dwyer DA, et al. Effects of conjugated linoleic acids (CLA) on tissue response to homeostatic signals and plasma variables associated with lipid metabolism in lactating dairy cows. J Anim Sci. 2002; 80(5):1285-93

7. Peterson DG, Matitashvili EA, Bauman DE. Diet-induced milk fat depression in dairy cows results in increased trans-10, cis-12 CLA in milk fat and coordinate suppression of mRNA abundance for mammary enzymes involved in milk fat synthesis. J Nutr. 2003;133(10):3098-102.

8. Bernard L. Expression and Nutritional Regulation of Lipogenic Genes in the Ruminant Lactating Mammary Gland, vol. 606. New York: Springer New York; 2008. p. 67-108.

9. Lee $\mathrm{SH}$, Hossner $\mathrm{KL}$. Coordinate regulation of ovine adipose tissue gene expression by propionate. J Anim Sci. 2002;80(11):2840-9.

10. Wakil SJ. Fatty acid synthase, a proficient multifunctional enzyme. Biochemistry-US. 1989;28(11):4523-30.

11. Corl BA, Baumgard LH, Dwyer DA, et al. The role of Delta (9)-desaturase in the production of cis-9, trans-11 CLA. J Nutr Biochem. 2001;12(11):622-30.

12. Griinari JM, Corl BA, Lacy SH, et al. Conjugated linoleic acid is synthesized endogenously in lactating dairy cows by Delta (9)-desaturase. J Nutr. 2000; 130(9):2285-91.

13. Corl BA, Baumgard LH, Griinari JM, et al. Trans-7, cis-9 CLA is synthesized endogenously by delta9-desaturase in dairy cows. LIPIDS. 2002;37(7):681-8.
14. Keating AF, Kennelly JJ, Zhao FQ. Characterization and regulation of the bovine stearoyl-CoA desaturase gene promoter. Biochem Biophys Res Commun. 2006;344(1):233-40.

15. Ahmad S, Anjum FM, Huma N, et al. Composition and physico-chemical characteristics of buffalo milk with particular emphasis on lipids, proteins, minerals, enzymes and vitamins. J Anim Plant Sci. 2013;23:62-74.

16. Bionaz $\mathrm{M}$, Loor JJ. Gene networks driving bovine millk fat synthesis during the lactation cycle. BMC Genomics. 2008;9(1):366.

17. Ren C, Wang L, Fan Y, et al. Scd1 contributes to lipid droplets formation in GMEC via transcriptional regulation of Tip47 and Adrp[J]. European Journal of Lipid Science and Technology. 2018;120(2):1700238.

18. Yao D, Luo J, He Q, et al. SCD1 alters long-chain fatty acid (LCFA) composition and its expression is directly regulated by SREBP-1 and PPARY 1 in dairy goat mammary cells. J Cell Physiol. 2017;232(3):635-49.

19. Bauman DE, Mather $I H$, Wall RJ, et al. Major advances associated with the biosynthesis of milk. J Dairy Sci. 2006;89(4):1235-43.

20. Shimomura I, Hammer RE, Richardson JA, et al. Insulin resistance and diabetes mellitus in transgenic mice expressing nuclear SREBP-1c in adipose tissue: model for congenital generalized lipodystrophy. Genes Dev. 1998; 12(20):3182-94.

21. Rodriquez-Cruz M, Sánchez R, Sánchez AM, et al. Participation of mammary gland in long-chain polyunsaturated fatty acid synthesis during pregnancy and lactation in rats. Biochimica Biophys Acta. 2011;1811(4):284-93.

22. Miyazaki M, Kim YC, Ntambi JM. A lipogenic diet in mice with a disruption of the stearoyl-CoA desaturase 1 gene reveals a stringent requirement of endogenous monounsaturated fatty acids for triglyceride synthesis. J Lipid Res. 2001:42(7):1018-24.

23. Kadegowda A, Bionaz M, Piperova LS, et al. Peroxisome proliferatoractivated receptor- $\gamma$ activation and long-chain fatty acids alter lipogenic gene networks in bovine mammary epithelial cells to various extents. J Dairy Sci. 2009;92(9):4276-89.

24. Bitter A, Nussler AK, Thasler WE, et al. Human sterol regulatory elementbinding protein 1a contributes significantly to hepatic lipogenic gene expression. Cell Physiol Biochem. 2015;35(2):803-15.

25. Shimomura I, Shimano H, Horton JD, et al. Differential expression of exons $1 \mathrm{a}$ and $1 \mathrm{c}$ in mRNAs for sterol regulatory element binding protein-1 in human and mouse organs and cultured cells. J Clin Invest. 1997;99(5):838-45.

26. Shimano $\mathrm{H}$, Horton JD, Shimomura I, et al. Isoform 1c of sterol regulatory element binding protein is less active than isoform 1a in livers of transgenic mice and in cultured cells. J Clin Invest. 1997;99(5):846-54.

27. Schoonjans K, Peinado Onsurbe J, Lefebvre A, et al. PPARalpha and PPARgamma activators direct a distinct tissue-specific transcriptional response via a PPRE in the lipoprotein lipase gene. EMBO J. 1996;15(19): 5336-48.

28. Miller CW, Ntambi JM. Peroxisome proliferators induce mouse liver stearoylCoA desaturase 1 gene expression. Proc Natl Acad Sci U S A. 1996;93(18): 9443-8.

29. Singh AH, Liu S, Crombie DL, et al. Differential effects of rexinoids and thiazolidinediones on metabolic gene expression in diabetic rodents. Mol Pharmacol. 2001;59(4):765-73.

30. Shi H, Luo J, Zhu J, et al. PPARy regulates genes involved in triacylglycerol synthesis and secretion in mammary gland epithelial cells of dairy goats. PPAR Res. 2013:2013:684159.

31. Bionaz M, Chen S, Khan MJ, et al. Functional role of PPARs in ruminants: potential targets for fine-tuning metabolism during growth and lactation. PPAR Res. 2013;2013:684159.

32. Ntambi JM. Regulation of stearoyl-CoA desaturase by polyunsaturated fatty acids and cholesterol. J Lipid Res. 1999;40(9):1549-58.

33. Rincon G, Islas-Trejo A, Castillo AR, et al. Polymorphisms in genes in the SREBP1 signalling pathway and SCD are associated with milk fatty acid composition in Holstein cattle. J DAIRY RES. 2012;79(1):66-75.

34. Zidi A, Fernández-Cabanás VM, Urrutia B, et al. Association between the polymorphism of the goat stearoyl-CoA desaturase 1 (SCD1) gene and milk fatty acid composition in Murciano-Granadina goats. J Dairy Sci. 2010;93(9): 4332-9.

35. Pauciullo A, Cosenza G, D'Avino A, et al. Sequence analysis and genetic variability of stearoyl $\mathrm{COA}$ desaturase (SCD) gene in the Italian Mediterranean river buffalo. Mol Cell Probe. 2010;24(6):407-10.

36. Loor JJ, Herbein JH. Reduced fatty acid synthesis and desaturation due to exogenous trans10, cis12-CLA in cows fed oleic or linoleic oil. J Dairy Sci. 2003;86(4):1354-69. 
37. Dobrzyn P, Pyrkowska A, Jazurek M, et al. Increased availability of endogenous and dietary oleic acid contributes to the upregulation of cardiac fatty acid oxidation. Mitochondrion. 2012;12(1):132-7.

38. Listenberger $\mathrm{LL}, \mathrm{Han} \mathrm{X}$, Lewis $\mathrm{SE}$, et al. Triglyceride accumulation protects against fatty acid-induced lipotoxicity. Proc Natl Acad Sci. 2003;100(6):3077-82.

39. Hulver MW, Berggren JR, Carper MJ, et al. Elevated stearoyl-CoA desaturase1 expression in skeletal muscle contributes to abnormal fatty acid partitioning in obese humans. Cell Metab. 2005;2(4):251-61.

40. Tian P, Luo Y, Li X, et al. Negative effects of long-term feeding of high-grain diets to lactating goats on milk fat production and composition by regulating gene expression and DNA methylation in the mammary gland. J Anim Sci Biotechno. 2017;8(1):74.

41. Mele M, Conte G, Castiglioni B, et al. Stearoyl-coenzyme a Desaturase gene polymorphism and Milk fatty acid composition in Italian Holsteins. J Dairy Sci. 2007;90(9):4458-65.

42. Brenaut $P$, Bangera $R$, Bevilacqua $C$, et al. Validation of RNA isolated from milk fat globules to profile mammary epithelial cell expression during lactation and transcriptional response to a bacterial infection. J Dairy Sci. 2012;95(10):6130-44.

43. Yadav P, Deepak Singh D, Mukesh M, et al. Identification of suitable housekeeping genes for expression analysis in mammany epithelial cells of buffalo (Bubalus bubalis) during lactation cycle. Livest Sci. 2012;147(1-3):72-6.

44. Cai X, Liu Q, Zhang X, et al. Identification and analysis of the expression of microRNA from lactating and nonlactating mammary glands of the Chinese swamp buffalo. J Dairy Sci. 2017;100(3):1971-86.

45. Li X, Li P, Wang $L$, et al. Lysine enhances the stimulation of fatty acids on Milk fat synthesis via the GPRC6A-PI3K-FABP5 signaling in bovine mammary epithelial cells. J Agr Food Chem. 2019;67(25):7005-15.

\section{Publisher's Note}

Springer Nature remains neutral with regard to jurisdictional claims in published maps and institutional affiliations.

Ready to submit your research? Choose BMC and benefit from:

- fast, convenient online submission

- thorough peer review by experienced researchers in your field

- rapid publication on acceptance

- support for research data, including large and complex data types

- gold Open Access which fosters wider collaboration and increased citations

- maximum visibility for your research: over $100 \mathrm{M}$ website views per year

At $\mathrm{BMC}$, research is always in progress.

Learn more biomedcentral.com/submissions 